\title{
GAMBARAN KECEPATAN PELAYANAN RESEP DI INSTALASI RAWAT JALAN RUMAH SAKIT ELIM RANTEPAO KABUPATEN TORAJA UTARA
}

\section{The Speed Description Of Reservation Prescription In Patient Instalation Of Elim Hospital North Toraja Rgion}

\author{
Estherina Allo Payung ${ }^{1 *}$, Sisilia Idayani ${ }^{2}$ \\ 1,2 Akademi Farmasi Toraja \\ "Koresponden Author : estherinaallopayung@gmail.com / Tlp. 081342136015
}

DOI: https://doi.org/10.32382/mf.v15i1.798

\begin{abstract}
ABSTRAK
Seiring semakin meningkatnya tuntutan masyarakat akan mutu pelayanan rumah sakit, maka perlu adanya upaya yang dilakukan utnuk memberikan pelayanan yang maksimal. Salah satu upaya yang dilakukan adalah dengan mengukur kecepatan pelanyan resep. Penelitian ini merupakan penelitian observasi untuk melihat gambaran kecepatan pelayanan resep. Jumlah responden sebanyak 410 yang diambil secara acak pada pasien yang datang berobat rawat jalan di Rumah Sakit Elim Rantepao selama bulan juli sampai Agustus 2018. Pengumpulan data dilakukan dengan cara menghitung waktu mulai resep diterima oleh petugas rawat jalan instalasi farmasi sampai obat diterima oleh pasien. Hasil penelitian menunjukkan rata-rata waktu penyelesaian resep racikan 37 menit, non racikan 30 menit.
\end{abstract}

Kata kunci: Resep racikan dan non racikan, Kecepatan pelayanan resep, pasien rawat jalan

\section{PENDAHULUAN}

Rumah Sakit adalah salah satu institusi pelayanan kesehatan yang menyelenggarakan pelayanan kesehatan perorangan secara paripurna yang menyediakan pelayanan rawat inap, rawat jalan dan gawat darurat. Salah satu tujuan rumah sakit adalah untuk mempermudah akses masyarakat untuk mendapatkan pelayanan kesehatan (Undang-Undang Nomor 44 tahun 2009).

Dewasa ini banyak tersedia institusi pelayanan kesehatan. Hal tersebut menimbulkan persaingan bisnis yang semakin kompetitif, sehingga mengubah cara berpikir masyarakat dalam memilih dan menilai mutu pelayanan kesehatan. Mutu tersebut merupakan salah satu tolok ukur kepuasan dan berdampak terhadap kembalinya pasien pada institusi yang memberikan pelayanan kesehatan yang efektif dan efisien sesuai dengan harapan mereka. Salah satu upaya untuk mengetahui mutu pelayanan rumah sakit adalah dengan cara mengetahui kecepatan pelayanan resep pasien rawat jalan, baik resep obat racikan maupun non racikan. Menurut standar pelayanan minimal rumah sakit dari Menteri Kesehatan Nomor 129/Menkes/SK/II/2008 tentang waktu penyelesaian resep yaitu $\leq 30$ menit untuk resep obat jadi dan $\leq 60$ menit untuk resep obat racikan. Menurut Nita Rusdiana dalam penelitiannya tentang kualitas pelayanan farmasi berdasarkan waktu penyelesaian resep di Rumah Sakit Umum Tangerang menyimpulkan bahwa waktu penyelesaian resep dokter yang memberikan jaminan kepuasan adalah kurang dari 13 menit dan didukung dengan hasil kuesioner yang dinyatakan dalam hasil tertinggi pada variabel daya tanggap sebesar 3,29 yang setuju bahwa waktu tunggu obat tidak lama. 
Rumah Sakit Elim Rantepao merupakan salah satu rumah sakit swasta kategori tipe $\mathrm{C}$ yang berada di bawah naungan Yayasan Gereja Toraja, berlokasi di jalan Ahmad Yani nomor 68 di kota Rantepao, kabupaten Toraja Utara. Rumah sakit ini mempunyai visi yaitu menjadi rumah sakit dengan pelayanan berkualitas, manusiawi dan terjangkau. Misi rumah sakit ini memberikan pelayanan kesehatan secara paripurna, menumbuhkan kebanggaan dan loyalitas yang tinggi bagi setiap karyawan, meningkatkan kinerja bagi karyawan, meningkatkan kepuasan bagi pelanggan serta menciptakan lingkungan rumah sakit yang baik dan nyaman.

Adapun Rumah sakit ini bekerjasama dengan Badan Penyelenggara Jaminan Sosial (BPJS) Kesehatan dan perusahaan asuransi lainnya. Dalam menjalankan tugas dan fungsinya, instalasi farmasi Rumah Sakit Elim Rantepao memiliki tenaga sebagai berikut: 4 orang tenaga Apoteker, 11 orang tenaga teknik kefarmasian dan 2 orang tenaga administrasi. Keberjalanan tugas dibagi menjadi 3 shift, yaitu pagi pukul $7.30-14.00$, sore pukul 14.00 - 21.00 dan malam pukul 21.00 08.00. Untuk pelayanan resep pasien rawat jalan, terdapat 4 petugas yang dikhususkan menanganinya dengan pembagian tugas masing-masing yaitu 1 orang bertugas mengambilkan obat, 1 orang bertugas mengemas, 1 orang bertugas meracik dan 1 orang bertugas menyerahkan obat.

Banyaknya resep yang dilayani setiap harinya menyebabkan tuntutan pelayanan yang cepat dan tepat. Terdapat pasien yang tidak mau menunggu obat dan berinisiatif untuk mengambil obatnya pada beberapa jam kemudian atau pada keesokan harinya. Hal ini merupakan suatu masalah, karena resep pada hari berikutnya akan menumpuk dan mempengaruhi kualitas pelayanan saat itu. Dari kondisi di atas menyebabkan perlu dilakukan penelitian untuk mengetahui berapa lama waktu yang digunakan untuk menyelesaiakan resep obat racikan maupun non racikan. Rumusan masalah pada penelitian ini adalah bagaimana gambaran kecepatan pelayanan resep pada pagi hari, siang hari dan malam hari di instalasi rawat jalan Rumah Sakit Elim Rantepao ?

\section{METODE}

\section{Jenis Penelitian, Tempat dan Waktu}

Penelitian ini merupakan penelitian observasi untuk melihat gambaran kecepatan pelayanan resep terhadap tingkat kepuasan pasien. Tempat penelitian dilakukan di Rumah Sakit Elim Rantepao Kecamatan Rantepao Kabupaten Toraja Utara. Waktu pelaksanaan penelitian dilakukan pada setiap hari Senin, Selasa, Rabu, Kamis, Jumat, Sabtu, dan Minggu pada pagi hari, hari pukul 09.00 WITA - 12.00 WITA, siang hari pukul 12.01 WITA - 17.00 WITA dan malam hari pukul 17.01 WITA - 21.00 WITA selama periode 9 Juli 2018 sampai 8 Agustus 2018.

\section{Populasi, Sampel dan Teknik Sampling}

Populasi dalam penelitian ini yaitu semua pasien rawat jalan yang berobat ke Rumah Sakit Elim Rantepao periode 9 Juli 2018 sampai 8 Agustus 2018. Sampel yang digunakan dalam penelitian ini ialah pasien rawat jalan di Rumah Sakit Elim Rantepao

\section{Teknik Sampling}

Sampel ditentukan dengan teknik sistematik random sampling dimana peneliti mengambil data setiap hari Senin, Selasa, Rabu, Kamis, Jumat, Sabtu, Minggu secara acak selama satu bulan berdasarkan responden pada saat dilakukan kegiatan penelitian.

\section{Instrumen Penelitian}

Instrumen pengumpulan data yang dibutuhkan dalam penelitian ini menggunakan alat pencatat waktu (Time Stemp). Bahan yang digunakan dalam penelitian ini adalah resep-resep pasien rawat jalan di instalasi farmasi 


\section{Teknik Pengumpulan Data}

Pengumpulan data dilakukan dengan cara menghitung waktu pelayanan secara bertahap dari tahap penerimaan resep, perhitungan harga, pembayaran, pengambilan obat, peracikan, pemberian etiket, pemberian informasi obat sampai obat diterima pasien.

\section{Cara Analisis Data}

Data yang diperoleh dipisahkan antara resep pelayanan pagi hari, siang hari dan malam hari, diolah dengan komputerisasi untuk mendapatkan nilai rata-rata pada setiap tahap pelayanan resep.racikan maupun non racikan. Hasil tersebut kemudian dibandingkan dengan pelayanan minimal rumah sakit dari Menteri Kesehatan Nomor 129/Menkes/SK/II/2008 tentang waktu penyelesaian resep yaitu $\leq 30$ menit untuk resep obat jadi dan $\leq 60$ menit untuk resep obat racikan. Data yang diperoleh akan disajikan dalam bentuk tabel.

\section{HASIL}

Pada penelitian yang telah dilakukan, jumlah subjek yang digunakan adalah 410 responden. Dari pengumpulan data kecepatan pelayanan resep yang dilakukan, diperoleh total rata-rata waktu pelayanan resep racikan yaitu pada pagi hari 42 menit 17 detik, siang hari 52 menit dan malam hari 26 menit. Sedangkan total ratarata waktu pelayanan resep non racikan yaitu pada pagi hari 25 menit, siang 43 menit, dan malam 23 menit.

\section{PEMBAHASAN}

Subjek yang diambil pada pagi hari pukul 09.00 WITA-12.00 WITA sebanyak 205 responden, pada siang hari pukul 12.01 WITA-17:00 WITA sebanyak 156 responden dan pada malam hari pukul 17:01 WITA-21:00 WITA sebanyak 49 responden. Pada pagi hari jumlah responden terdiri dari 189 pasien menggunakan resep BPJS, 16 pasien dengan resep umum. Pada siang hari terdiri dari 132 pasien dengan resep BPJS dan
24 Pasien dengan resep umum, sedangkan pada malam hari terdiri dari 8 pasien menggunakan resp BPJS dan 41 pasien menggunakan resep umum. Jenis resep pada pagi hari terdapat resep racikan sebanyak 36 lembar, resep non racikan 120 lembar, pada siang hari terdapat 12 resep racikan dan 144 resep non racikan dan pada malam hari terdapat 1 lembar resep racikan dan 48 lembar resep non racikan.

Dari pengumpulan data kecepatan pelayanan resep yang dilakukan, terdapat beberapa tahapan. Pada tahap pertama adalah penerimaan resep dokter oleh petugas instalasi farmasi rawat jalan dari pasien yang kemudian petugas memberikan nomor antrian, pada saat tersebut mulai dilakukan perhitungan waktu pelayanan. Tahap selanjutnya adalah pemberian harga yang dilakukan setelah resep diterima oleh petugas instalasi farmasi rawat jalan. Pemberian harga dilakukan bagi pasien yang menggunakan resep umum, sedangkan pasien yang menggunakan resep BPJS atau pasien dari perusahaan yang bekerjasama dengan pihak rumah sakit tidak dilakukan pemberian harga. Tahap selanjutnya adalah pembayaran yang dilakukan pasien di loket pembayaran.

Tahap yang keempat adalah pengambilan obat, pada tahap ini dilakukan oleh petugas yang ditunjuk untuk mengambilkan obat. Tahap kelima adalah peracikan. Untuk tahap ini hanya berlaku bagi resep yang obatnya harus diracik terlebih dahulu.Tahap selanjutnya adalah pemberian etiket. Sedangkan tahap pemberian infomasi obat (PIO) adalah tahap ketujuh dan yang terakhir adalah tahap penyerahan obat yang dilakukan oleh petugas instalasi farmasi setelah pasien mendapatkan PIO

Waktu rata-rata yang digunakan untuk tahap penerimaan hingga tahap pemberian harga adalah 20 detik pada pagi hari, pada siang hari 1 menit dan malam hari 1 menit. Pada tahap pemberian harga hingga tahap pembayaran pada pagi hari 
membutuhkan waktu 1 menit 34 detik, siang hari 3 menit dan malam hari 50 detik. Tahap pembayaran hingga tahap pengambilan obat membutuhkan waktu yaitu pada pagi hari 9 menit 13 detik, siang hari 13 menit dan malam hari10 menit 24 detik. Untuk tahap pengambilan obat hingga peracikan adalah: pagi hari membutuhkan waktu 8 menit, pada siang hari 8 menit 50 detik dan malam hari 3 menit. Adapun waktu yang digunakan dalam peracikan hingga pemberian etiket adalah: pada pagi hari membutuhkan waktu 11 menit 6 detik, pada siang hari 12 menit, malam hari5 menit. Tahap pemberian etiket hingga tahap PIO pada pagi hari adalah 11 menit 10 detik, siang hari 14 menit, malam hari 4 menit 44 detik.Pada tahap PIO hingga obat diserahkan waktu yang dibutuhkan adalah pada pgi hari 54 detik, siang hari 1 menit dan malam hari 54 detik. Sehingga total pelayanan rsep racikan pada pagi hari adalah 42 menit 17 detik, siang hari 52 menit dan malam hari 26 menit. waktu rata-rata yang digunakan pada penyelesaian resep non racikan pada pagi hari dari tahap penerimaan resep hingga perhitungan harga adalah 20 detik, siang hari 1 menit dan malam hari 1 menit, dari perhitungan harga hingga pembayaran pada pagi hari waktu yang digunakan 1 menit 34 detik siang hari 1 menit dan malam hari 1 menit., dari pembayaran hingga pengambilan obat pada pagi hari waktu yang digunakan adalah 6 menit 48 detik, siang hari 13 menit dan malam 10 menit 21 detik. Pada tahap pengambilan obat hingga pemberian etiket waktu pagi hari membutuhkan waktu 7 menit, siang hari 8 menit malam hari 5 menit. Dari tahappemberia etiket hingga pemberian PIO waktu yang dibutuhkan pada pagi hari mewmbutuhkan 8 menit 24 detik, siang hari 17 menit dan malam 4 menit 40 detik Pada tahap akhir dari tahap PIO hingga obat diterima pasien, pada pagi hari membutuhkan waktu 54 detik, siang 1 menit dan malam butuh 1 menit. Sehingga total pelayanan resep non racikan pada pagi hari adalah 25 menit, siang hari 43 menit dan malam 23 menit. Jadi pelayanan yang tercepat terjadi pada malam hari dan pelayanan terlama terjadi pada siang hari.

Dari data yang diperoleh dapat disimpulkan bahwa kecepatan pelayanan resep adalah 37 menit menit.untuk resep racikan dan 30 menit untuk penyelesaian obat non racikan. Hal ini menunjukkan bahwa kecepatan pelayanan resep di instalasi rawat jalan R.S Elim Rantepao sesuai dengan standar pelayanan minimal rumah sakit dari Menteri Kesehatan N0.129/Menkes/SK/II/2008 tentang waktu penyelesaian resep yaitu $\leq 30$ menit untuk resep obat jadi dan $\leq 60$ menit untuk resep obat racikan.

\section{KESIMPULAN}

Berdasarkan hasil penelitian yang dilakukan di Instalasi Rawat Jalan Rumah Sakit Elim Rantepao diketahui bahwa waktu rata- rata penyelesaian resep racikan pada pagi hari 43 menit 17 detik, siang hari 52 menit, dan malam hari 26 menit.Pada resep non racikan waktu rata-rata yang digunakan pada pagi hari adalah 25 menit, siang hari 43 menit dan malam hari 23 menit. Waktu penyelesaian resep racikan adalah 37 menit dan non racikan 30 menit Pelayanan tercepat terjadi pada malam hari, pelayanan terlama pada siang hari dan pada tahap pemberian etiket hingga tahap PIO adalah tahap terlama dalam pelayanan resep.

\section{SARAN}

Dari hasil penelitian yang dilakukan maka penulis memberikan saran bagi Rumah Sakit Elim Rantepao perlunya penambahan petugas Instalasi Farmasi untuk dapat meningkatkan mutu pelayanan khususnya dalam penyelesaian resep rawat jalan.

\section{DAFTAR PUSTAKA}

Priyandani, Yuni, dkk (2014), Pemberian Informasi Lama Terapi dan Konfirmasi Informasi Obat Perlu Ditingkatkan di Puskesmas, Jurnal Farmasi dan Ilmu KefarmasianIndonesia, Vol 1 No 1 
Peraturan Mentri Kesehatan Republik Indonesia No.72 Tahun 2016 Tentang Standar Pelayanan Kefarmasian di Rumah Sakit

Undang-Undang Republik Indonesia No.44 Tahun 2009 Tentang Rumah Sakit

Erwinayanti G.A.P.S., 2013. Pengukuran Kinerja Instalasi Farmasi Rumah Saklit Umum Daerah Penembahan Senopati Bantul dengan Pendekatan Balanced Scorecard,Tesis,Fakultas Farmasi, Universitas Gadjah Mada, Yogyakarta

Arwani, Mukhlis dan Ernawati, Nina 2013. Pengaruh Kualitas Pelayanan Fasilitas dan Harga Terhadap Kepuasan Pasien (Studi Kasus Pada RS PKU Muhammadiyah Gubug). JurnalQ-Man. Vol. 2, No. 2. Hal116

Herjunianto, dkk. 2014. Faktor yang Mempengaruhi Cakupan Layanan Farmasi di Instalasi Rawat Jalan Rumah Sakit. Jurnal Kedokteran Brawijaya. Vol 28, No.1. Hal 8-13

Wati, Wirdah, dkk. 2013. Evaluasi Pengelolaan Obat dan Strategi
Perbaikan dengan Metode Hanlon di Instalasi Farmasi Rumah Sakit Umum Daerah Karel Sadsuituhun Kabupaten Maluku Tenggara tahun 2012. Prosiding Seminar Nasional Perkembangan Terkini Sains Farmasi dan Klinik III 2013, Hal 247-257

Fitriah N, 2016. Penyebab dan Solusi Lama Waktu Tunggu Pelayanan Obat di Instalasi Farmasi Rawat Jalan Rumah Sakit. (onlne) diakses pada http//jkb.ub.ac.id/index.php/jkb/arti cle/Yiew/1634 pada 28 februari 2017

Rusdiana, 2015. Kualitas pelayanan farmasi berdasarkan waktu penyelesaian resep di rumah sakit, (online) diakses pada Http://journal uade.ac.id/index.php/PARMACIA NA/acticle/view/2439/1801 diakses 10 Juni 2017

Soemarsono T, 2015. Pengantar studi Farmasi. Jakarta: BUKU KEDOKTERAN EGC 
Tabel 1. Data sampel yang digunakan dalam penelitian

\begin{tabular}{|c|c|c|c|c|c|}
\hline \multirow{2}{*}{$\begin{array}{c}\text { Pelayanan } \\
\text { resep }\end{array}$} & \multirow{2}{*}{$\begin{array}{c}\text { Jumlah } \\
\text { resep }\end{array}$} & \multirow[b]{2}{*}{ Resep BPJS } & \multirow{2}{*}{$\begin{array}{l}\text { Resep } \\
\text { Umum }\end{array}$} & \multicolumn{2}{|c|}{ Jenis resp } \\
\hline & & & & Racikan & $\begin{array}{c}\text { Non } \\
\text { Racikan }\end{array}$ \\
\hline Pagi & 205 & 189 & 16 & 36 & 120 \\
\hline Siang & 156 & 132 & 24 & 12 & 144 \\
\hline Malam & 49 & 8 & 41 & 1 & 48 \\
\hline Total & 410 & 329 & 81 & 89 & 312 \\
\hline
\end{tabular}

Tabel 2. Kecepata pelayanan resep racikan.

\begin{tabular}{|c|c|c|c|c|c|c|c|c|}
\hline \multirow[b]{2}{*}{$\begin{array}{c}\text { Waktu } \\
\text { pelaya } \\
\text { nan }\end{array}$} & \multicolumn{7}{|c|}{ Rata-rata waktu pelayanan } & \multirow[b]{2}{*}{ Total } \\
\hline & $\begin{array}{c}\text { Terima } \\
\text { resep- } \\
\text { pember } \\
\text { ian } \\
\text { harga }\end{array}$ & $\begin{array}{c}\text { Pember } \\
\text { ian } \\
\text { harga- } \\
\text { pembay } \\
\text { aran }\end{array}$ & $\begin{array}{l}\text { Pembaya } \\
\text { ran- } \\
\text { pengamb } \\
\text { ilan }\end{array}$ & $\begin{array}{l}\text { Pengambil } \\
\text { an- } \\
\text { peracikan }\end{array}$ & $\begin{array}{l}\text { peracikan- } \\
\text { pemberian } \\
\text { etiket }\end{array}$ & $\begin{array}{l}\text { Pemberian } \\
\text { etiket-PIO }\end{array}$ & $\begin{array}{c}\text { Pemberian } \\
\text { PIO- obat } \\
\text { diterima } \\
\text { pasien }\end{array}$ & \\
\hline Pagi & $\begin{array}{c}20 \\
\text { detik }\end{array}$ & $\begin{array}{l}1 \text { menit } \\
34 \text { detik }\end{array}$ & $\begin{array}{l}9 \text { menit } \\
13 \text { detik }\end{array}$ & 8 menit & $\begin{array}{l}11 \text { menit } 6 \\
\text { detik }\end{array}$ & $\begin{array}{l}11 \text { menit } \\
10 \text { detik }\end{array}$ & 54 detik & $\begin{array}{c}42 \\
\text { menit } \\
17 \\
\text { detik }\end{array}$ \\
\hline Siang & 1 menit & 3 menit & 13 menit & $\begin{array}{c}8 \text { menit } \\
\text { detik }\end{array}$ & 12 menit & 14 menit & 1 menit & $\begin{array}{c}52 \\
\text { menit }\end{array}$ \\
\hline Malam & 1 menit & 50 detik & $\begin{array}{l}10 \text { menit } \\
24 \text { detik }\end{array}$ & 3 menit & 5 menit & 4 menit 44 & 54 detik & $\begin{array}{c}26 \\
\text { menit }\end{array}$ \\
\hline
\end{tabular}

Tabel 3. Kecepatan pelayanan resep non racikan

\begin{tabular}{|c|c|c|c|c|c|c|c|}
\hline \multirow[b]{2}{*}{$\begin{array}{c}\text { Waktu } \\
\text { pelayanan }\end{array}$} & \multicolumn{6}{|c|}{ Rata-rata waktu pelayanan } & \multirow[b]{2}{*}{ Total } \\
\hline & $\begin{array}{l}\text { Terima } \\
\text { resep- } \\
\text { pemberian } \\
\text { harga }\end{array}$ & $\begin{array}{l}\text { Pemberian } \\
\text { harga- } \\
\text { pembayara } \\
\mathrm{n}\end{array}$ & $\begin{array}{l}\text { Pembayaran- } \\
\text { pengambilan }\end{array}$ & $\begin{array}{l}\text { Pengambilan } \\
\text {-pemberian } \\
\text { etiket }\end{array}$ & $\begin{array}{l}\text { Pemberian } \\
\text { etiket- PIO }\end{array}$ & $\begin{array}{l}\text { PIO- } \\
\text { Penyerahan }\end{array}$ & \\
\hline Pagi & 20 detik & $\begin{array}{l}1 \text { menit } 34 \\
\text { detik }\end{array}$ & $\begin{array}{l}6 \text { menit } 48 \\
\text { detik }\end{array}$ & 7 menit & $\begin{array}{l}8 \text { menit } 24 \\
\text { detik }\end{array}$ & 54 detik & \multirow{3}{*}{$\begin{array}{l}25 \\
\text { menit } \\
43 \\
\text { menit } \\
23 \\
\text { menit }\end{array}$} \\
\hline Siang & 1 menit & 3 menit & 13 menit & 8 menit & 17 menit & 1 menit & \\
\hline Malam & 1 menit & 1 menit & $\begin{array}{l}10 \text { menit } 21 \\
\text { detik }\end{array}$ & 5 menit & $\begin{array}{l}4 \text { menit } 40 \\
\text { detik }\end{array}$ & 1 menit & \\
\hline
\end{tabular}

